\title{
ALTERATIONS OF CELL-MEDIATED IMMUNE RESPONSE IN CHILDREN WITH FEBRILE SEIZURES
}

\author{
TEREZINHA C.B. MONTELLI*, ANGELA M.V.C. SOARES**, MARIA R. PARISE-FORTES**, \\ MARIA T. REZKALLAH-IWASSO**, NIURA M.R. PADULA*, MARIA TEREZINHA S. PERAÇOLI*
}

\begin{abstract}
The aim of the present investigation was to study the distribution of T-cell subsets in peripheral blood defined by monoclonal antibodies and by the lymphocyte proliferative response to phytohemagglutinin (PHA) in 30 children with febrile seizures and in 14 age-matched control subjects. Frequent respiratory, urinary and dermatologic infections were observed in 22 patients. The immunologic parameters showed that $64 \%$ of the patients presented an increased number of CD8+ cells and a low helper/suppressor ratio was observed in $60 \%$ of the patients. In addition, the proliferative response of lymphocytes to PHA was impaired in the patients. It was observed the presence of inhibitory activity on lymphocyte function in the plasma of $33 \%$ of children with febrile seizures. These results suggest that patients with febrile seizures have an impairment of cellular immunity that may be connected with this epileptic syndrome and explain the infections observed.
\end{abstract}

KEY WORDS: febrile seizures, infections, $T$ cell subsets, lymphocyte proliferative response.

\section{Alteraçōes da resposta imune celular em crianças portadoras de convulsāo febril}

RESUMO - O objetivo da presentc investigação foi estıdar a distribuição das subpopulações de células T por meio de anticorpos monoclonais e a resposta proliferativa de linfócitos em resposta a fito-hemaglutinina (PHA) em 30 crianças portadoras de convulsão febril e cm 14 crianças saudáveis de mesma faixa etária dos pacientes. Infecçōes respiratórias, urinárias e dermatológicas frequentes foram observadas em 22 pacientes. Os parâmetros imunológicos demonstraram que $64 \%$ dos pacientes apresentaram valores elevados de células CD8+. Diminuição da relação de células CD4/CD8 foi observada em 60\% dos pacientes. Além disso, a resposta proliferativa de linfócitos frente a PHA apresentou-se deprimida nos pacientes. Foi observada a presença de atividade inibidora da função de linfócitos no plasma de 33\% das crianças com convulsão febril. Esses resultados sugerem que pacientes com convulsāo febri] apresentam depressão da resposta imune celular que poderia implicar $\mathrm{em}$ associação patogêtrica com esta síndrome epiléptica e explicar as infeçōes observadas. linfócitos.

PALAVRAS-CHAVE: convulsāo febril, infecções, subpopulaçōes de linfócitos T, resposta proliferativa de

A febrile seizure is the most common convulsive disorder of early childhood. It may occur between 3 months and 6 years of age, associated with fever but without evidence of intracranial infection or defined cause". Febrile seizures are to be distinguished from epilepsy which is characterized by recurrent nonfebrile seizures ${ }^{3}$. Febrile seizures usually occur in children who are developmentally normal but may be also present in children with precxisting neurologic or developmental abnormalities? ${ }^{7}$ The most frequent cause of illnesses in children presenting the first

*Depatment of Neurology and Psychiatry, School of Medicine and **Department of Microbiology and Immunology, Institute of Biosciences (IB), State University of São Paulo (UNESP), Botucatu, São Paulo, Brazil. Aceite: $27-$ janeiro-1997. 
febrilc scizurc is viral infection". These infections usually affect the upper respiratory airways, the middle ear, and the gastrointestinal tract. Seizures that occur after DPT or measles immunization, may be related in response to temperature elevation".

Reduced serum IgA levels have been observed in children with febrile seizures presenting recurrent infections due to an immunodeficient status ${ }^{21,22}$. Immunological disturbances such as low levels of immunoglobulins in serum and alterations in $\mathrm{T}$ cell subsets of peripheral blood such as diminished number of CD4+ cells and increased CD8 + cells has been observed in patients with complex partial seizures and primary generalized tonic-clonic seizures ${ }^{5,4}$. Association with intense immunological dysfunction has been described in serious epileptic encephalopaties of childhood such as West and Lennox-Gastaut syndromes, with deficiency of cell-mediated immune response and altered levels of serum immunoglobulins ${ }^{12,14}$. In addition, patients with West syndrome prescnted decreased CD3+, CD4+ subset and CD4/CD8 ratio while CD8+ cells were elevated ${ }^{13}$.

These results suggest that some abnormalities of the immune response may be associated with syndromes and epileptic episodes. Thus, the objective of the present investigation was to study cell-mediated immunity in children with febrile seizures, considered to be a benign form of childhood special epileptic syndrome of usually transitory course. Also, to introduce the question about a possible physiopathologic linkage between cellular immunity with febrile convulsions.

\section{MATERIAL AND METHODS}

Patients and controls. A group of 30 children, 19 male and 11 female, with diagnosis of febrile seizures, seen at Hospital das Clínicas, UNESP, Botucatu, State University of São Paulo, were included in the study. The criteria for include children with febrile seizures in this study were: 1 . to have been attended in the outpatient clinic since the first convulsion; 2 . to have regular follow-up, in order to permit a carefull prospective study; 3 . to have good nutrition condition. There was no selective procedure about characteristics of febrile seizures, neither frecpuency of infections. Age at the first febrile seizure rniged from 3 months to 5 years (median age 1.3 years). The seizure episodes were short in 27 patients, with a duration of less than 10 minutes, and prolonged in three of the children. Generalized crisis were observed in 29 patients and a hemigeneralized crisis was observed in one child. The control group included 14 healthy subjects ( 8 males and 6 females) whose age range was similar to that of the patients.

Immunity was evaluated out of periods of infections, during the follow-up of the patients, six or more months after convulsive episodes. Informed consent was obtained from the parents of patients and controls. The authors had approval from Hospital Ethics Commission to study immunocompetence in children with convulsive disorders.

Antecedents. Recurrence of febrile seizures was reported by 20 children, and 10 had presented only one seizure episode before the present immunological cvaluation. A family history of febrile seizures was verified in 4 children and was absent in 14 patients. Family history of epilepsy was observed in 9 children, and association of epilepsy plus febrile seizures was present in 3 patients. Seventeen children were submitted to continuous treatment with phenobabital, and one was treated with valproate. Twelve patients were left untrented.

Reapentr. Monoclonal antibodies directed against human $\mathrm{CD} 3+$ and $\mathrm{CD} 4+$ and CD8+ were obtained from Ortho Dingnostics Systems (Raritan, NJ, USA) and were employed throughout this study. For the indirect immunofluorescence assay, biotinylated horse anti-mouse IgG and fluorescein-labelled avidin-D (Vector Laboratories, Burlingame, PA, USA) were used.

Enumeration of lymphocyte subsets. Peripheral blood mononulear cells were isolated from heparinized venous blood by Ficoll-Hypaque density centrifugation and resuspended in RPMI 1640 medium (Gibco Laboratories, Grand Island, NY, USA) supplemented with $10 \%(\mathrm{v}: \mathrm{v})$ fetal calf serum. Approximately $2 \times 10^{5}$ cells werc centrifuged onto a poly-l-lysinc-coated coverslip and staining reactions carricd out at $4^{\circ} \mathrm{C}$ as described previously ${ }^{23}$. Briefly, after reacting with the monoclonal antibody, the cells were treated with biotinylated horse anti-mouse IgG and fluoresceinated avidin-D and fixed in formaldehyde. At least 500 cells per sample were examined and scored under phase and fluorescence microscopy.

Lymphocyte proliferative response. Lymphocyte cultures were prepared according to Musatti et al." ". Peripheral heparinized blood was obtained from patients and normal control subjects. After separation of mononuclear 
cells by Ficoll-Hypaque density centrifugation, the concentration of the cells was adjusted to $5 \times 10^{5} \mathrm{cells} / \mathrm{ml}$ in RPM medium containing $20 \%$ homologous $\mathrm{AB}$ or autologous heat-inactivated plasma. Each culture test tube received 2.5 $\mathrm{ml}$ of this suspension and triplicates were prepared receiving 40 ug of phytohemagglutinin-P (PHA). Control tubes did not receive any stimulus. Tritiated thymidine, $2 \mu \mathrm{Ci}$ specific activity $6.7 \mathrm{Ci} / \mathrm{mM}$ (New England Nuclear, Boston, MA. USA), was added to each tube for eight hours before termination of the culture. The cultures were harvested after $72 \mathrm{~h}$ of incubation. Isotope incorporation by harvested cell cultures was counted in a Beckman liquid scintillation espectrometer. The results are expressed as counts of radiation emission per minute (cpm) and defined as "blastogenic index" (BI) which is the ratio: cpm of stimulated tubes/cpm of control tubes. Based on the response of healthy controls, $\mathrm{BI}>20$ were considered to be positive.

Statistical analysis. The results from patients and control groups were analysed by Student $\mathrm{s} t$ test. Significant valucs are considered to occur at $p<0.05$. Altered results were considered when excecded \pm 2 SD mean values of controls.

\section{RESULTS}

Frequent infectious episodes were detected in 22 of the 30 children with febrilc seizures studied. Recurrent upper respiratory infections werc obscrved in 17 patients, more than two episodes of pneumonias in 8, urinary infections in 4 and mycotic infection of the skin was present in 4 children. Primary tuberculosis infection was observed in one child after BCG vaccine (attenuated agent), requiring treatment with hydrazide. Clinical manifestation was regional axillar lymphadenitis and fever. Also, one child presented flaccid paralysis of the lower extremities with no sensory loss, and with complete recovery. Only 8 of 30 patients studied did not present frequent infections.

Table 1 shows the percentage of total $\mathrm{T}$ cells (CD3+), helper inducer (CD4+), cytotoxic/ suppressor (CD8+) T-ccll subscts and the CD4:CD8 ratio detected in peripheral blood of patients and healthy controls. Although the mean values of the percentages of CD3+ and CD4+cells werc comparable to that of the controls, a decreased proportion of these cells was observed in 5 and 11 children, respectively. A significant increase in proportion of CD8 + T cells was detected in $64 \%$ of the patients, and a consequent reduction in CD4:CD8 ratio was observed in $60 \%$ of the children with febrile seizures.

The lymphocyte proliferative response to PIIA was impaired in the patients when compared to the control group (Table 2). This depression of cell-mediated immune responsc was observed to the same extent when the cells of the patients were cultivated in presence of human $A B$ plasma (homologous plasma) or in paticnt s plasma (autologous plasma). Moreover it was delected a presence of an inhibitory activity of the patient's plasma on lymphocyte function in 6 out 18 (33\%) of the patients as observed by the analysis of blastogenic index presented in Figure 1.

The inhibitory effect of patients plasma

Table l. Percentuges of T cell subsets in patients with febrile seizure and in a heallhy control group.

\begin{tabular}{cccc}
\hline $\begin{array}{c}\text { CD+cell } \\
\text { subsets }\end{array}$ & $\begin{array}{c}\text { Patients } \\
(n=30)\end{array}$ & $\begin{array}{c}\text { Controls } \\
(n=14)\end{array}$ & Significance* \\
\hline CD3+ & $59.4 \pm 8.4$ & $62.2 \pm 9.2$ & NS \\
CD4+ & $36.1 \pm 10.4$ & $40.2 \pm 4.2$ & NS \\
CD8+ & $26.1 \pm 4.7$ & $22.4 \pm 1.8$ & $p<0.05$ \\
CD4/CD8 & $1.41 \pm 0.5$ & $1.80 \pm 0.2$ & $p<0.05$ \\
\hline
\end{tabular}

Results are expressed as me ill \pm standard deviation.

-Students l lest. on lymphocyte proliferative response of cells obtained from healthy controls stimulated with PHA was observed by the impaired response of these cells. Pooled plasma of 4 patients that presented an inhibitory effect of their plasma on their own cells, also inhibited the lymphoproliferative response of 4 healthy people cells stimulated by PHA. The level of the lymphoproliferative inhibition was about $74 \%$ when the patient:s plasma was added to the culture (cpm with $\mathrm{AB}$ plasma $=29,159.37 \pm 4,521.0 ; \mathrm{cpm}$ with pooled patient $\mathrm{s}$ plasma $=7,678.25 \pm 1,673.72$ ) .

In the present study. there was no association between cellular immunity alterations 
Table 2. Lymphocyte proliferative response to phytohemaglutinin in patients with febrile seizures and in a healthy' contol groulp.

\begin{tabular}{|c|c|c|c|c|c|}
\hline \multirow{2}{*}{$\begin{array}{l}\text { Cells cultured } \\
\text { with }\end{array}$} & \multicolumn{2}{|c|}{ Patients } & \multicolumn{2}{|c|}{ Controls } & \multirow[t]{2}{*}{ Significance } \\
\hline & $\mathrm{cpm}$ & $\mathrm{Bl}^{*}$ & cpm & B! & \\
\hline $\begin{array}{l}\text { Homologous } \\
\text { plasma }\end{array}$ & $\begin{array}{l}25,132 \\
\pm 18,58.5\end{array}$ & 19.9 & $\begin{array}{l}55,585 \\
\pm 18,531\end{array}$ & 35.6 & $p<0.05$ \\
\hline $\begin{array}{l}\text { Autologous } \\
\text { plasma }\end{array}$ & $\begin{array}{l}21,663 \\
\pm 16,003\end{array}$ & 16.8 & $\begin{array}{l}53,481 \\
\pm 16,969\end{array}$ & 34.8 & $p<0.05$ \\
\hline
\end{tabular}

Results are expressed ats nein \pm standatrd deviation.

* $\mathrm{BI}=$ blastogenic index: **Student $s \mathrm{t}$ test

and therapy, age at the first febrile seizure, number of seizure episodes, or frequency of infectious diseases

\section{DISCUSSION}

This study demonstrated that children with febrile seizure episodes exhibited abnormalities in the cell-mediated immune response. One relevant observation is that none of the children presented abnormalities in all parameters studied, but all of them showed altered responses, to at least one or more of the tests employed to evaluate immunocompetence.

The low CD4:CD8 ratio observed may have been related to the increase proportion of CD8+ T cells observed in $64 \%$ of the patients. Eeg-Olofsson et al. ${ }^{6}$ described immunological alterations in 24 adult patients with partial seizures such as: low levels of IgA, and small proportions of CD4+ cells and high proportions of CD8 + cells. It is interesting to notice that 7 out of 24 patients had febrile seizures during infancy. These authors ${ }^{5}$ also studied 50 patients with partial complex and generalized primary tonic-clonic seizures and described low CD4+ proportion, high CD8+ proportion

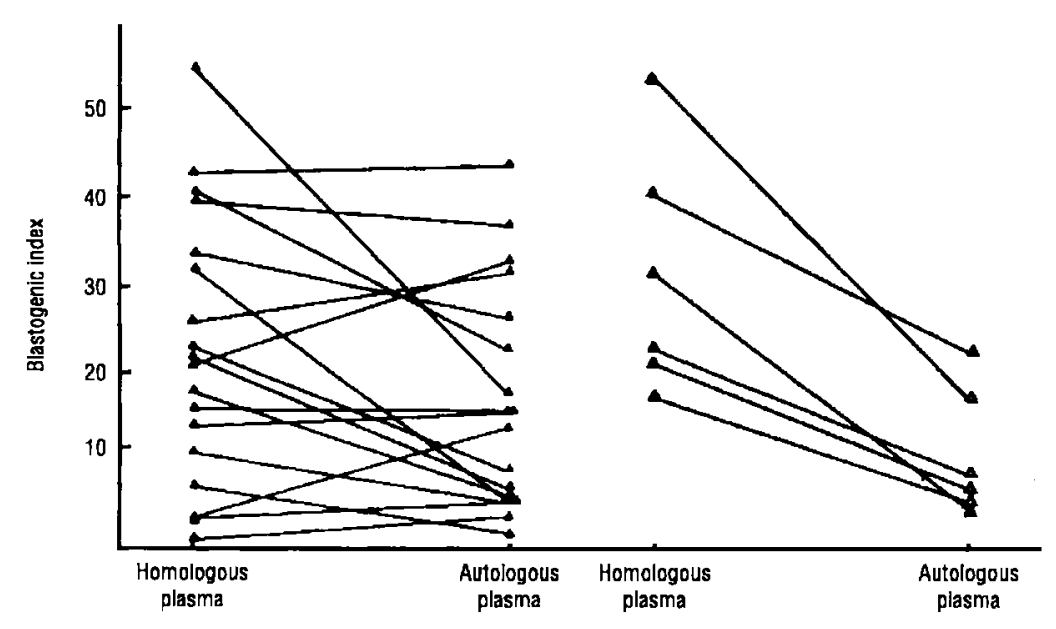

Fig I. Effect of homologous ve autologous plasma of patients with febrile seizures on lymphocyte proliferative response of phytohemagglutinin (A). Inhibitory activity of autologous plasma was present in $33 \%$ of the patients $(B)$. Results are expressed as blastogenic index. 
and Jow CD4:CD8 ratio. They did not find association of these immune alterations with therapy, and considered that these type of epilepsy might be associated with a deficient genetic regulation that also affects the immune system. Thus, the variable intensity of the alterations in cellular immunity observed in epilepsy may be accounted for by heredity with the same genetic determinants involved, but perhaps in a multifactorial manner ${ }^{5}$.

The importance of the genetic mechanisms involved in epilcpsy has been emphasized. The presencc of a family history of nonfebrile epilepsy is a well known factor that enhances the probability of future progression to epilepsy. In febrile seizures there is a genetic predisposition, but the exact pattern of heredity is unknown. If the parents had a previous child who had febrile convulsions, the risk of another child to be affected is one in five ${ }^{2}$. Moreover, a family history of febrile scizures also plays a role in the risk of recurrence ${ }^{17}$.

The impairment in lymphocyte proliferative response to PHA observed in the children with febrile seizures, suggests a depression of this cellular immune reactivity. Besides, the plasma inhibitory factors detected in $33 \%$ of the patients reduced $\mathrm{T}$-lymphocyte prolifcration of patientslymphocytes and of lymphocytes from healthy controls cultured with the plasma of patients with febrile seizures, suggesting that these factors might inhibit cellular immunity. In fact, 22 (73\%) of the patients presented frequent infectious episodes, indicating susceptibility to recurrence and resistance to treatment, as observed in mycotic skin infections. These results suggest that there may be an association between cellular immune dysfunction and the pathophysiology of febrile seizures. If this is confirmed, the treatment of infections in children with febrilc seizure episodes should be re-evaluated. Care should be taken to prevent infection by specific therapeutic or preventive measures and with immunization mainly with attenuated microorganisms such as polio and measles virus. The occurrence of paralysis induced by the vaccinal poliovirus in immunodeficient children has been reported ${ }^{16.19 .24}$. We observed a primary tuberculosis infection after BCG vaccination in one child with febrile seizures, presenting suppression of cell-mediated immune function. Thus, immunothcrapy could be employed as an adjuvant measure in treatment of febrile seizures. Furthcr researches may lead to conclude for a true syndrome of cell-mediated immune dysfunction and febrile seizures, or to an incidental and intriguing finding of our study.

Some observations have suggested a control of the immune response by the central nervous system. The immune system receives signals from the brain and neuroendocrinc system via the autonomic nervous system and hormones and sends information to the brain, via cytokines. The regulatory reciprocal influences that exist between the brain and the immune system appear to be neccssary for coordination of behavioral and physiological responses to infection and inflammation ${ }^{4}$.

Specific receptors for many neuroendocrine and nervous system mediating factors have becn identified in immunocompetent cells ${ }^{10,21}$ and these factors may also modulate the immune response indircctly by affecting the production or activity of lymphokines and cytokincs. ${ }^{9.15}$. In addition, the effects of conditioning procedures or stress on the suppression of humoral and cell-mediated immune response have been confirmed in recent studies'.

If the reciprocal influences between central nervous system and immunc responsc are confirmed, the relationship between epileptic diseases and immunological dysfunctions may bc better understood, leading to important changes in the management of epilepsy.

Acknowledgements - The authors are grateful to Mrs Maria Antonia M. Palma for technical assistance and to Mrs Sonia Maria Faraldo for typing the manuscript.

\section{REFERENCES}

1. Ader R. On the clinicul relevance of psychoneuroimmunology. Clin Immunol Immunopithol 1992;64:6-8.

2. Baraitser M. Relevunce of a fumily history of seizures. Arch Dis Child 1983;58:404-405.

3. Consensus Statement: Febrile Seizures: Long-term management of children with fever-associated seizures. Pediatrics 1980:66:1009-1012. 
4. Dantzer R. Kelley KW. Stress and immunity: an integrated view of the relationship between the brain and the immune system. Life Sci 1989;44:1995-2008.

5. Eeg-Olofison O. Ostcrlind CK. Guttman RD, Andermann F, Prchal JF, Anderminn E, Janguà NA. Immunological studies in focial epilepky. Acta1 Neurol Scand 1988:78:358-368.

6. Eeg-Ololision O, Prchal JF, Andermann F. Abnormalities of T-lymphocyte subsets in epileptic patients. Acta Neurol Scind 1985:72:140-144.

7. Hirtz DG. Generalized tonic-clonic and febrile seizures. Ped Clin North Am 1989;36:365-383.

8. Hirtz DG, Nelson KB, Ellenberg JH. Seizures following childhood immunizations. J Pediat 1983;120:14-18.

9. Johnson HM, Torres BA. Regulation of lymphokine production by arginine vasopressin and oxytocin: modulation of lymphocyte function by neurohypophyse:al hormones. I Immunol 1985;135:773s-775s.

10. Khimsari DN. Murgo A.I. Fiath RE. Effects of stress on the immune system. Immunol Today 1990;11:170-175.

11. Lewis HM. Parry IV. Paury RP. Davies A, Sanderson PJ. Tyriell DAJ, Valmun HB. Role of viruses in febrile convulsions. Arch Dis Child 1979:54:869-876.

12. Montelli TCB. Mota NGS, Peraçoli MTS, Torres EA, Rezkallah-Iwasso MT. Immunological disturbances in West and IennoxGastaut syndromes. Arg Neuropsiquiatr 1984;42: I32-I 39.

13. Montelli TCB, Perıçoli MTS, Soures AMVC, Rezkallalı-Iwasso MT, Pauisc-Fortes MR, Alquati SAB, Medeiros P, De Lucea E. Sensibilidade mutugênica, attividade de células natural killer e distribuiçâo de subpopulaçōes de linfócitos Tem pácientes: com síndrome de West: resultados preliminares. Arq Neuropsiquiatr 1992:50(Suppl): 115.

14. Montelli TCB, Rezkallial-Iwasso MT, Pelaçoli MTS, Mota NGS. Imunologic disturbance in West and Lennox-Gástiut syndromes and in cpilepy with independent multifocal spikes. Cleveland Clin I Med 1989;56:S-285.

15. Munck A, Guyre PM, Hollbrook NJ. Physiological functions of glucocorticoid actions. Endocinol Rev 1984:5:25-44.

16. Musatti CC. Rezkallah-Iwasso MT, Mendes E. Mendes NF. In vivo and in vitro evaluation of cell-mediated immunity in paticnts with paracoccidioidomycosis. Cell Jmmunol 1976;24:365-378.

17. Nelson KB. Ellenberg.JH. Prognosis in children with febrile seizurcs. Pcdiatrics 1978;61:720-727.

18. Querfurth H, Swanson P. Vaccine-issociated paralytic poliomyelitis. Aich Neurol 1990;4:541-544.

19. Sakano 'T, Kittakat F, Tanaka Y, Yamanka H, Kobayashi Y, Usui 'T'. Vaccine-associated poliomyelitis. Acta Pediatr Scand 1980;69:545-551.

20. Seager J, Wilson J. Jamilson DZ, Hayard MR, Loothil JF. IgA deficiency, epilepsy and phenytoin treatment. Lancet I975;2:632-635.

21. Sell S. The immune response. In: Sell S. (ed): Immunology, Immunopithology and Immunity, New York: Elsevier: 1987;199-233.

22. Tartala A, Verri AP, Nespoli I, Moglia A, Botta MG. Immunological findings in epileptic and febrile convulsion patients before and under treitment. Eur Neurol 1981;20:306-311

23. Van Voothis WC. Hair LS, Steinman RM, Kaplan G. Human dendritic cells: enrichment and challacterization from peripheral blood. J Exp Med 1980;155:1172-1187.

24. Wright PF. Hatch MH, Kasselberg AG. Lowry SA, Wadlington WB, Kalzon DT. Vaccine-associated poliomyelitis in a clild with sex linked agimmiglobulinemia. J Pediat 1977;91:408-412. 